8) Maeyama $T$ : Experimental sinusitis in rabbits. Auris Nasus Larynx $8: 87 \sim 98,1981$.

9) 前山拓夫, 大山 勝：感染症の実験モデルと化学 療法一耳鼻科. 抗生物質から化学療法の領域 | : 853 861, 1985.

10）前山拓夫, 大山 勝: 副鼻腔炎の病態一実験的副 鼻腔炎を中心に. 頭頸部外科・耳鼻咽唉科 Mook. 75 82頁, 金原出版, 東京, 1985.
11）藤谷哲造，他：慢性副鼻腔炎上㖽洞粘膜内一の抗 生物質浸透性におよぼす蛋白分解䣼素の影響. 耳 鼻臨床 $66: 557 \sim 565,1973$.

12）馬場駿吉：消炎醉素剤一耳鼻咽唉科領域. $66 \sim 70$ 頁, ライフ・サイエンス出版, 東京, 1977 .

13）大山 勝：上気道粘膜の病態生化学. $8 \sim 10$ 頁, 斯文堂, 鹿児島, 1984.

\title{
副鼻腔炎に対する抗生剂の選択と 他剤の併用
}

石田稔

鼻副鼻腔炎の急性期はウイルス感染でアレル ギーの関与, 鼻轱形態の異常が加わって治癒が 遷延化する. したがってての時期は抗生剂投与 の対象にはなり得ないが，乙れに続発する細菌 感染症は抗生剂投与の有効性が確立しており, 副鼻腔炎の起炎菌を知り, 抗生剂の選択を行う ことは日常診療を行う上で重要である.

まず急性, 慢性時, 鼻腔之副鼻腔, 副鼻腔粘 膜之眝留液などの検出菌の差異を知り, 臨床分 離菌のM I Cを考慮に入れた抗生剂の選択を行 う必要がある.

新しいセフェム剂によって今まで困難を極め ていた各種 $\beta$-lactamase 産生グラム陰生桿菌 の治療はやりやすくなったものの, 各種抗生剂 を乱用することによって耐性菌の増加をみてい る. 抗生剂の副作用も考虑に入れ薬剂の特徵を よく把握した上で選択する必要がある.

副鼻腔炎患者に抗生剂を投与する場合, 主に 内服剂で，血管内投与をおこなうことは稀であ る. 副鼻腔組織への移行も血中の半分以下で低 いためエアロゾルによる局所療法が日常診療に 取入れられている. この他慢性副鼻腔炎時酵素 剂の併用療法むおてなわれている.
細菌検査の際，鼻腔に刘しては綿棒を川鼻道 に挿入し鼻汁を採取する，上顎润に対しては穿 刺術をおてない採取, 検鏡する。

表 1 は急性炎症時グラム陰性の Haemophilus influenzae があっとも多く，つづいてグ ラム陽性の Streptococcus aureus, Streptococcus pheumonia が多いが, 慢性化すると Staphylococcus epidermis などのグラム陽性 菌が主流を占めてくる，乙れは中耳炎の起炎菌 の頻度に似ている。

\section{鼻腔と副鼻腔の検出菌}

副鼻腔内よりの検体の $50 \%$, 鼻腔内の $33 \%$ に 菌は認めなかった。鼻腔では表 2 の如くStaphylococcus epidermis があっとも多く,つ づいて Streptococcus pyogenes とほとんよ゙ は好気性菌であるが上顎洞内ではむしろ $\mathrm{Pep}-$ tococcus, Peptostreptococcus などの嫌気性 菌が $48.6 \%$ を占めている. 鼻腔と副鼻腔では 細菌の成育の環境が異なっているものと考え る.

\section{副鼻腔貯留液と粘膜内の検出菌}

副鼻腔貯留液内で菌が検出されたものは21例 け9 例, 粘膜内で菌が検出されたものは21例中 
表 I 急性・慢性時の鼻腔内検出菌の比較

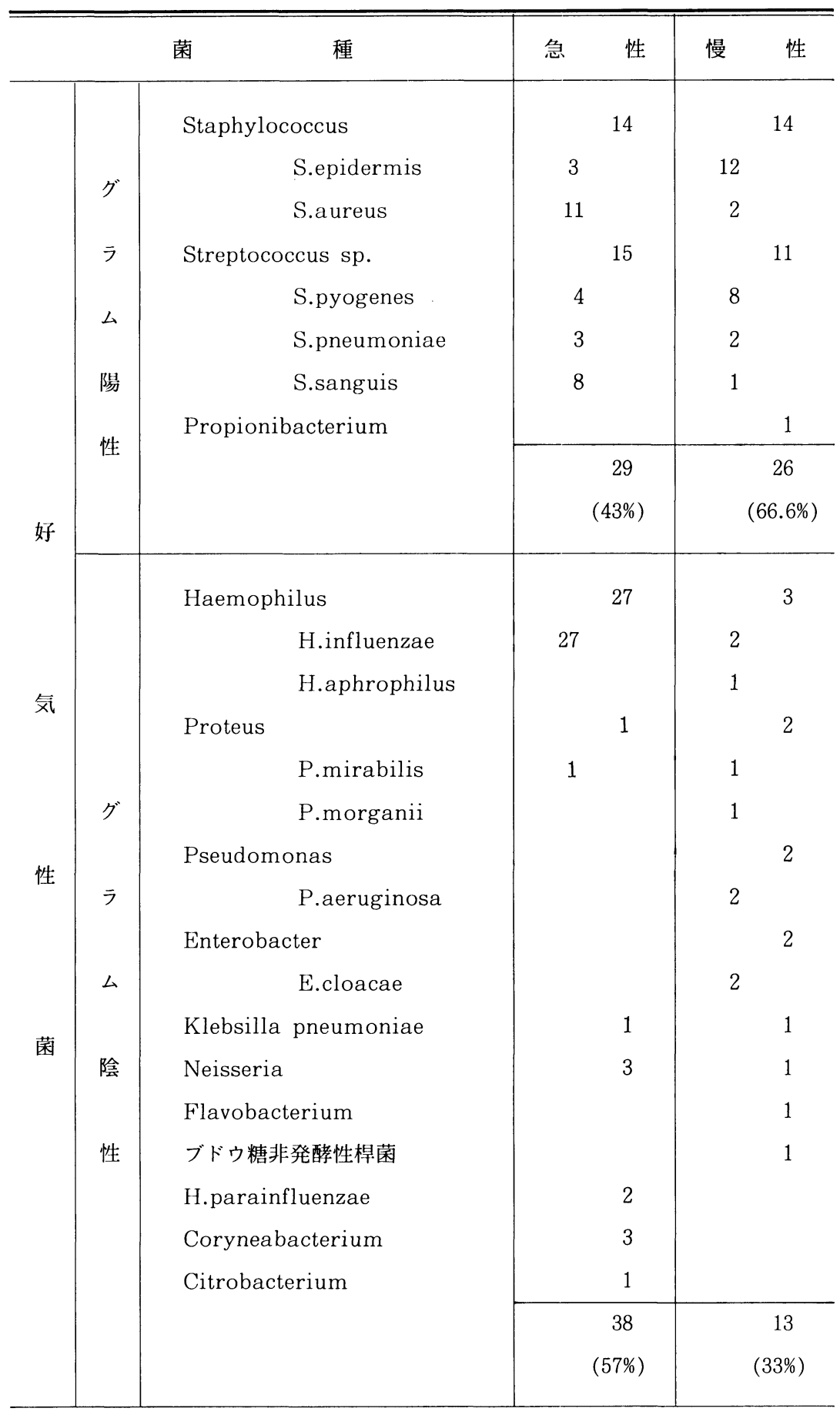


表 2 鼻腔と副鼻腔の検出菌の比較

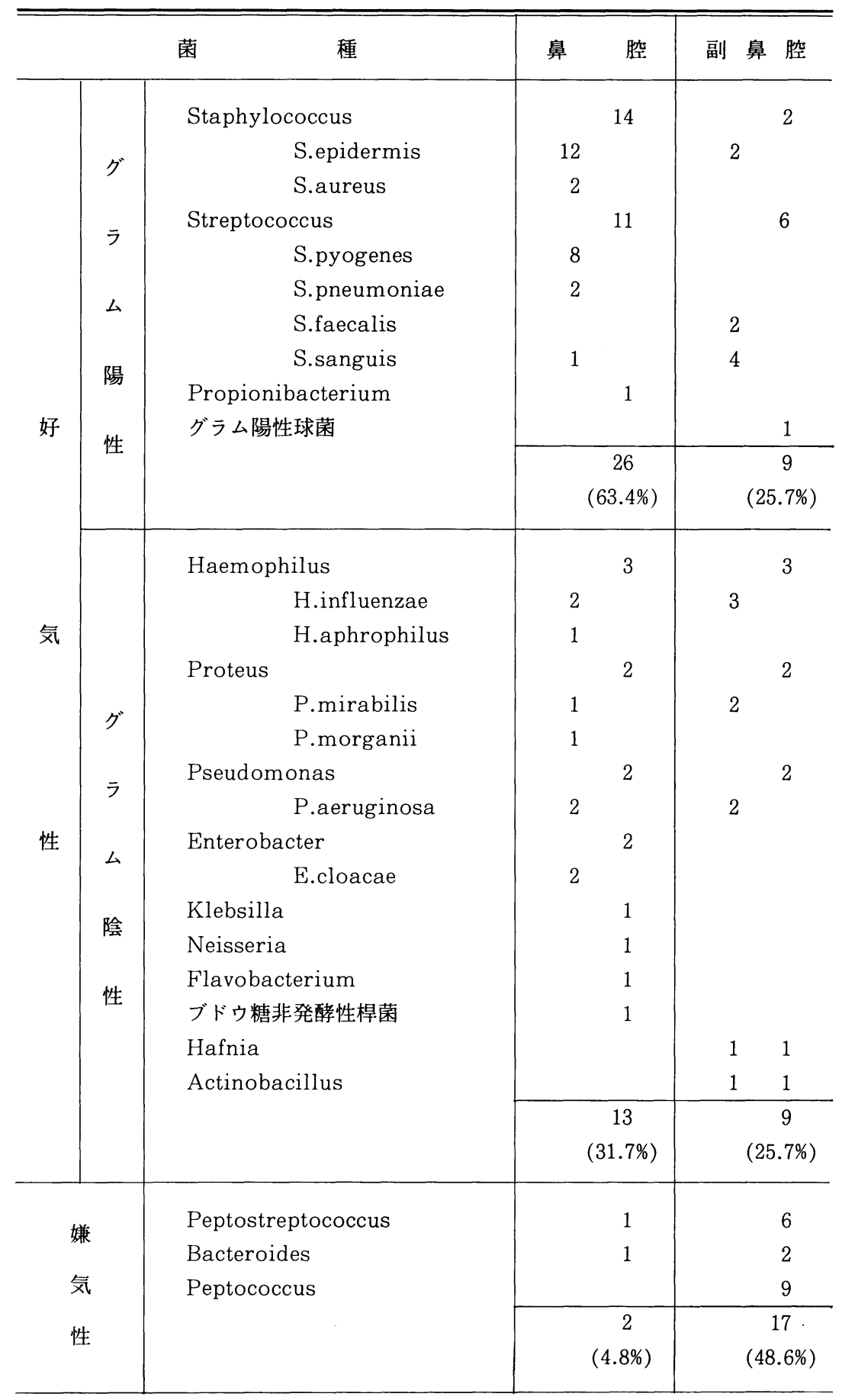


18例であった，貯留液中には38\%にしか菌をみ とめなかった。

両者に検出菌をみたもののうち貯留液之粘膜 内に同一菌をみとめたものは 21 例中 6 例であっ た，貯留液には嫌気性菌をみるととが多く，粘 膜内には好気性菌を多く認めた。このととは副 鼻腔炎の炎症の場が粘膜にあり, 貯留液はその 結果の粘液分泌物の排泄の場で嫌気性環境にあ るものと考える。

\section{抗生剂の臨床分離菌に対する最小発育阻止濃度}

ブドウ球菌, レンサ球菌, 肺炎球菌, インフ ルエンザ菌には従来よりのアンピシリンと共に セフェム系各剂，ノルフロキサシンなどの化学 療法剂が効果をみとめるが, 変形菌, 緑膿菌に 対してはアミカシン, ゲンタマイシン, 嫌気性 のバクテロイデスにはドキシサイクリン，リン コマイシン，ミノサイクリンが効果をみる.

以上の分離菌に対するM I C in vitro の 結果であり実際の臨床的薬効之は一致しないこ ともある。また，経口投与された抗生剂も血中 濃度の $30 \%$ 程度しか副鼻腔粘膜へ移行しにくい こともあり, 治癒し難い時は他の治療法を考元 る必要がある。

急性炎症には Haemophilus influenzae を 考慮に入れたA B P C，七ファクロールを使用 する。

慢性炎症にはグラム陽性菌を考えに入れた A B P C，七フェム系を用いる．嫌気性菌感染 が疑われる時, ミノサイクリン, リンコマイシ ン，ドキシサイクリンを使用する。しかしイン フルエンザ菌では A B P C 耐性菌の出現が問題 で，その場合ドキシサイクリン，ミノサイクリ ンかセフェム系かを使用する.

全身投与の場合, 副作用の乙と, 局所粘膜移 行が充分でないととああり, 副鼻腔炎疾患には 局所注入すなわち抗生剂の洗浄又は抗生剂を中 心としたエアロゾル療法が日常晾療に久かすと とが出来ない.

\section{ネブライザー等に用いる薬剤}

副鼻腔炎患者に抗生剂, 副腎皮質ホルモン,
酵素剂を含む溶解液をエアロゾルとして用い る. 気道洗浄薬としてアレベール, 重曹水, 生 食水, 蒸留水を用い, 喀痰溶解のためビソルボ ン，エレース，塩化リゾチームを加える．乙れ らのエアロゾルが副鼻腔へ入るととは少ないが 鼻腔内を清掃する意味でも重要であり，全身投 与では毒性が強すぎる抗生剂でもエアロゾルで は副作用も少なく気道全面に与えられることで 有意義である.

治療前に起炎菌の同定をし最適の抗生剂を与 える必要があるがエアロゾル療法の場合，その 抗生剂の性質すなわち粘膜刺激性, 苦味, 抗原 性，安定性などあ考虑に入れる。したがってア ミノ配糖体系がもっとも使用しやすい.

\section{消炎酵素剂の吸収と局所移行}

副鼻腔炎時, 細菌性のプロナーゼ, セラチ才 ペプチターゼ，多糖類のリゾチームが多く用い られている.

粘稠性の分泌物内の蛋白分解， ムコ多糖類分 解により排膿を促進し，炎症性産物の清掃の意 味, さらに抗生剂之酵素剂の併用により抗生剂 の組織内浸透が高まる。

しかし，今まで経口投与された酵素剂が腸管 吸収され，局所に移行するかどうかは疑問視さ れていた。最近種々の実験的手段で解明されつ つある。あっとあよく使用されている醉素剂の プロナーゼとリゾチームでみると腸管よりは数 \%の範囲で吸収されるとと，プロナーゼの場合 血中にある $\alpha_{2}$-macroglobulin が inhibitor の役割を演じ抗原性を抑えつつ炎症局所ではな れ，プロナーゼ本来の作用を示すむのと考元 られている。一少リゾチーム屯腸管吸収された のち局所へ移行して内因性リゾチーム活性を高 め炎症組織を治瘾任到らしめるものと考えられ る.

以上副鼻腔炎に対する抗生剂を主とする楽剂 の選択をおこない，急性，慢性の場合，すなお ち急性時非ステロイド系, 塩化リゾチーム薬剂 を併用し，慢性時蛋白分解酵素剂を用いる。

副鼻腔炎の治療の原則は病因を除いて鼻腔通 
気をよくすること，副鼻腔よりの排膿を改善す ることである，乙のため抗生剂，酵素剂をまず 投与すると同時にエアロゾル療法む行われる. しかし治癒し難い難治性のもの, 鼻副鼻空, 粘 膜形態がすでに不可逆的に変化したものは手術 をおこなう必要がある.
副鼻腔炎を引き起こす, いわゆる風邪症候群 に対して分泌型 IgA およびリゾチームを用い 粘膜上で防禦し得るもの之考える. 将来予防的 意味もかねて, 鼻副鼻腔炎の初期には各種細菌 に対するワクチン療法, 分泌型 IgA, リゾチー ムの局所利用も考えに入れる必要がある.

\title{
扁桃炎に対する抗生剤の選択と 他剤の併用
}

\author{
木下治二
}

\section{はじめに}

扁桃炎法耳鼻咽喉科領域の代表的かつ最もポ ピュラーな細菌感染症の一つであり．その治療 には抗生物質, 合成抗菌剂などが主として用い られる。一般に急性扁桃炎は抗菌化学療法がよ く奏効する感染症ではあるが，適切な薬剂選执 にはその臨床細菌学的な動向を熟知しておくと ともに，各薬剂がどのような組織移行性を示す かを参考にすることあ大切である，また，扁桃 炎の治療上，どのような楽剂を併用するのが合 理的であるかを知っておくことあ必要である. そのような観点からわれわれの知見亡考え方を 述べてみたい。

\section{急性扁桃资からの検出菌の動向}

われわれの臨床における最近約 1 年間の急性 陰窩性扁桃炎患者 118 例からの検出菌の動向は 表 1 亿示すでとくで, 病原性があると考えられ る菌種では Streptococcus pyogenes が25\% で最む高い頻度を示し，乙れ之ほぼ同種と考え られる $\beta$-streptococcus を加えると $34 \%$ とな る. 次いで Staphylococcus aureus の頻度 が高く, その他 Streptococcus pneumoniae, Haemophilus influenzae など一般に上気道
感染に関与しやすい菌種が検出されている，病 原的意義の明らかでない $\alpha$-streptococcus, Neisseria のみが検出された頻度もかなり高い が，てれらについての検討が今後必要之思われ る.

しかし，いずれにしても急性扁桃炎の原因菌 はStreptococcus 属を主体とするグラム腸性 球菌が多く，それにインフルエンザ菌や最近 注目されはじめた Branhamella catarrhalis などのグラム陰性菌に注意を払うべきであろ

表 I 急性陰窩性扁桃炎（118例）汃らの検出菌

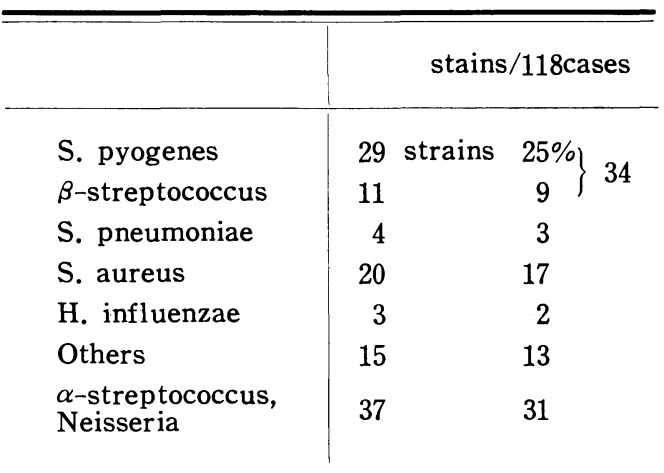

（名古屋市大） 